\title{
Characterisation of Plesiomonas shigelloides strains that share type-specific antigen with Shigella flexneri 6 and common group 1 antigen with Shigella flexneri spp. and Shigella dysenteriae 1
}

\author{
M. J. ALBERT*, M. ANSARUZZAMAN, F. QADRI, A. HOSSAIN, A. K. M. G. KIBRIYA, K. HAIDER, \\ S. NAHAR, S. M. FARUQUE and A. N. ALAM
}

International Centre for Diarrhoeal Disease Research, Bangladesh, Dhaka, Bangladesh

\begin{abstract}
Summary. Three strains of Plesiomonas shigelloides isolated from patients with diarrhoea were agglutinated with Shigella flexneri 6 antiserum in slide and tube tests. All the strains were also agglutinated with a monoclonal antibody to the common group 1 antigen shared between $S$. flexneri serotypes and $S$. dysenteriae type 1 . Further studies with one strain also showed sharing of antigenicity in an enzyme-linked immunosorbent assay. The results suggest that the strains share type-specific antigen with $S$. flexneri 6 and the common group 1 antigen with $S$. flexneri serotypes and $S$. dysenteriae 1 . The sharing of antigens may have implications for cross-protection. One strain adhered to HEp-2 cell monolayers. None of the strains contained high mol. wt plasmids and there was no sequence homology with the invasiveness plasmid of Shigella spp. in DNA probe hybridisation. They were susceptible to the commonly used antibiotics. However, they possessed four other virulence-associated properties of Shigella spp. that included Congo-red binding, hydrophobicity, toxicity to HeLa cells and HEp-2 cell invasiveness (although they gave negative results in the Sereny test for invasiveness). These data suggest that the three unique strains might be considered pathogenic. Studies in animal models and human volunteers would be necessary to establish their pathogenic potential.
\end{abstract}

\section{Introduction}

Plesiomonas shigelloides is a member of the family Vibrionaceae, and has been associated with diarrhoeal illness and other diseases. ${ }^{1}$ However, its enteropathogenicity is poorly understood as the isolates give generally negative results in the virulence tests for established enteropathogens. ${ }^{2-4}$ Strains of $P$. shigelloides that cross-react with Shigella sonnei, $S$. dysenteriae 7 and 8 and $S$. boydii 13 have been reported. ${ }^{5}$ In our clinical laboratory, we have monitored $P$. shigelloides strains that cross-react with shigellae. During 1991, three strains of $P$. shigelloides were isolated from patients with diarrhoea that crossreacted with $S$. flexneri 6 . Further studies suggested that they also shared a common group 1 antigen with $S$. flexneri serotypes and $S$. dysenteriae 1 . These strains have been characterised for the basis of their crossreactions and also studied by standard laboratory methods to determine whether they shared established

Received 9 Nov, 1992; accepted 2 Feb. 1993

* Corresponding author: Dr M. John Albert, Laboratory Sciences Division, ICDDR,B, GPO Box 128, Dhaka 1000 Bangladesh. virulence properties with diarrhoeagenic bacteria, including shigellae.

\section{Materials and methods}

\section{Patients and bacteria}

The three strains of $P$. shigelloides $(12726,22074$ and 12254) were isolated from the faeces of three patients with diarrhoea. Patients from whom strains 22074 and 12254 were isolated were 4 years old and had bloody, mucoid diarrhoea. The other patient was 6 years old and had watery diarrhoea.

Diarrhoeal stools obtained on admission were cultured for Salmonella, Shigella, Vibrio, Campylobacter, Aeromonas and Plesiomonas spp. by standard methods. ${ }^{6,7}$ Only $P$. shigelloides was isolated from these patients. $P$. shigelloides strains were identified by the API-20E system (API System, Montalieu, Vercieu, France) and reactions in conventional tests as described elsewhere. ${ }^{8}$ The three isolates gave biochemical reactions characteristic of $P$. shigelloides. ${ }^{8}$ Slide agglutination tests were performed with shigella antisera (Wellcome Diagnostics) with live and boiled cells.

Single strains of other bacteria used in the studies 
(table I) were from the culture collection of the International Centre for Diarrhoeal Disease Research, Bangladesh (ICDDR, B).

\section{MASFB monoclonal antibody}

This immunoglobulin $\mathbf{M}$ mouse monoclonal antibody (MAb) (ascites fluid) was a gift from N. Carlin, National Bacteriological Laboratory, Stockholm, Sweden. It reacts with the common group 1 antigenic epitope present in the lipopolysaccharide (LPS) structures of all $S$. flexneri serotypes and $S$. dysenteriae $1 .^{9}$

\section{Production of antisera}

Antisera were produced against $P$. shigelloides strain 12726 and a local strain of $S$. flexneri 6 . Bacteria were grown in trypticase soy broth supplemented with yeast extract $0.6 \%$ (TSBY; Gibco, Grand Island, NY, USA) overnight at $37^{\circ} \mathrm{C}$ as stationary cultures. The growth was pelleted by centrifugation, washed once in physiological saline and reconstituted in physiological saline to $10^{9}$ bacteria $/ \mathrm{ml}$. Adult New Zealand White rabbits were immunised intravenously at 6-day intervals with $0 \cdot 2,0.5$ and three $1.0-\mathrm{ml}$ doses of bacterial suspension. A booster dose of $2 \mathrm{ml}$ was administered 20 days after the last injection. The rabbits were exsanguinated 7 days after the last dose.

\section{Preparation of bacterial LPS}

Bacteria were grown overnight at $37^{\circ} \mathrm{C}$ in TSBY with shaking. The bacterial cells were pelleted at $6000 \mathrm{~g}$ for $30 \mathrm{~min}$ and used for the preparation of LPS by the hot phenol-water extraction procedure ${ }^{10}$ and purified by ultracentrifugation at $100000 \mathrm{~g}$ for $4 \mathrm{~h}$.

\section{Tube agglutination test}

The antigens used consisted of bacterial growth obtained after overnight still culture in TSBY at $37^{\circ} \mathrm{C}$, washed in physiological saline, boiled for $1 \mathrm{~h}$ and adjusted to a turbidity corresponding to that of McFarland standard no. 3. Doubling dilutions of antisera, starting at 1 in 50, were tested. Results were read after incubating the test tubes containing antigenantibody mixtures in a water-bath at $42^{\circ} \mathrm{C}$ for $1 \mathrm{~h}$ and then at $4^{\circ} \mathrm{C}$ overnight.

\section{Enzyme-linked immunosorbent assay (ELISA)}

ELISA was performed ${ }^{11}$ with LPS $(10 \mu \mathrm{g} / \mathrm{ml})$ as the coating antigen for the determination of antibody titre. Doubling dilutions of antisera starting with 1 in 1000 dilutions were added to the LPS-coated wells. The rabbit antibody was detected by horseradish peroxidase-conjugated swine immunoglobulins to rabbit immunoglobulins, and mouse antibody by horseradish peroxidase-conjugated rabbit immunoglobulins to mouse immunoglobulins (Dakopatts,
Denmark), both diluted ( 1 in 1000) in PBS containing Tween-20 0.1\%. Bound peroxidase was detected with $O$-phenylenediamine dihydrochloride as substrate. The reaction was stopped after $15 \mathrm{~min}$ with $4 \mathrm{~N}$ sulphuric acid, and optical density (OD) was measured at $492 \mathrm{~nm}$ in a Titertek multiscan spectrophotometer. The antibody titre was the highest dilution that gave an OD of 0.2 above control with pre-immune rabbit sera or a non-reactive mouse ascites fluid.

\section{Electrophoretic analysis of LPS}

Components of the purified LPS were separated by SDS-PAGE with gels $13.5 \% .^{12}$ The separated components were visualised by silver staining. ${ }^{13}$

\section{Cell-culture adherence assay}

Adherence to HEp-2 cell monolayer was tested according to the method of Cravioto et al. ${ }^{14}$ Briefly, HEp-2 cell monolayers were inoculated with overnight still cultures grown in Luria broth at $37^{\circ} \mathrm{C}$ and were then incubated for $3 \mathrm{~h}$ in the presence and absence of D-mannose $1 \%$. After washing to remove nonadherent bacteria, cells on coverslips were fixed in methanol $70 \%$ and stained with Giemsa. A localised adherence (LA)-positive strain of enteropathogenic Escherichia coli (EPEC) serotype O127:H6 and a nonadherent strain of $E$. coli (a derivative of $E$. coli $\mathrm{K}-12$, EC101, ${ }^{15}$ hereafter referred to as $E$. coli $\mathrm{K}-12$ EC101) were used as positive and negative controls respectively.

\section{Cell-culture invasion assay}

HEp-2 cell invasion assay was performed as described by Small and Falkow ${ }^{\mathbf{1 6}}$ with some modifications. Bacterial cells were grown with shaking for $4 \mathrm{~h}$ in TSBY at $37^{\circ} \mathrm{C}$. Approximtely $1 \times 10^{6} \mathrm{cfu}$ were added to a HEp-2 cell monolayer $\left(1 \times 10^{5}\right.$ cells in a 6$\mathrm{ml}$ vial, Kimble, Toledo, $\mathrm{OH}$, USA, containing Eagle's minimum essential medium, [MEM]), centrifuged at $800 \mathrm{~g}$ for $10 \mathrm{~min}$, and then incubated at $37^{\circ} \mathrm{C}$ for $2 \mathrm{~h}$ in an atmosphere of $\mathrm{CO}_{2} 5 \%$, air $95 \%$. After washing to remove non-adherent bacteria, the monolayer was incubated for $1 \mathrm{~h}$ in MEM containing gentamicin $100 \mu \mathrm{g} / \mathrm{ml}$ to kill extracellular bacteria. After washing the monolayer, internalised bacteria were released by lysis of the cells with Triton X100 and quantified by plate count. The positive and negative controls included were a strain of $S$. flexneri $2 \mathrm{a}$ and $E$. coli $\mathrm{K}-12$ EC101 respectively. Each strain was tested three times in duplicate, and the values were averaged. The isolates were also exposed to MEM containing gentamicin (without HEp-2 cells) to ensure that they did not survive the antibiotic treatment.

\section{Sereny test}

Shigella-like invasiveness was investigated by the Sereny test in guinea-pig eyes ${ }^{17} 4$ - and 20 -h shaker cultures in TSBY incubated at $37^{\circ} \mathrm{C}$ were tested. The $S$. flexneri 2 a strain was included as a positive control. 


\section{DNA hybridisation}

The DNA probe used was constructed from the invasiveness plasmid of $S$. flexneri 5 (M9OT) and consisted of a 17-kb EcoRI digestion fragment of pRM $17 .{ }^{18}$ The appropriate restriction fragment was purified as described by Moseley et al. ${ }^{19}$ The probe was labelled by nick-translation ${ }^{20}$ with $\left[\alpha^{32}-\mathrm{P}\right] \mathrm{dCTP}$ (Amersham International plc, Aylesbury, Bucks) and a nick-translation kit (Bethesda Research Laboratory, Bethesda, MD, USA). Colony blots were prepared, processed and hybridised under stringent conditions as described by Echeverria et al. ${ }^{21}$

\section{Plasmid analysis}

Bacterial plasmids were extracted by the methods of Birnboim and Doly ${ }^{22}$ and Kado and Liu, ${ }^{23}$ separated by agarose gel electrophoresis and stained by ethidium bromide as described previously. ${ }^{24}$

\section{Enterotoxin and cytotoxin production}

Bacteria were grown as shaken cultures in TSBY at $37^{\circ} \mathrm{C}$ for $20 \mathrm{~h}$. Supernates sterilised by membrane filtration $(0.45 \mu \mathrm{m}$ pore size; Millipore Corp, Bedford, MA, USA) were used for enterotoxin and cytotoxin assays. Heat-labile enterotoxin was tested in Y1 adrenal tumour cells, ${ }^{25}$ heat-stable enterotoxin in suckling mice ${ }^{26}$ and cytotoxin in HeLa cells. ${ }^{27}$ The positive controls included were filter-sterilised supernates from an $E$. coli strain that produced heat-labile and heat-stable enterotoxins (for $\mathrm{Y} 1$ cell assay and suckling mouse assay) and $S$. dysenteriae 1 (for HeLa cell assay). Neutralisation of cytotoxicity for HeLa cells was done by mixing equal volumes of a 1 in 10 dilution of rabbit antiserum to Shiga toxin with ten $50 \%$ cytotoxic doses of toxin contained in filtered supernates and then incubating the mixtures for $1 \mathrm{~h}$ at $37^{\circ} \mathrm{C}$, followed by overnight incubation at $4^{\circ} \mathrm{C}$. Rabbit antiserum to Shiga toxin was elicited against purified Shiga toxoid ${ }^{28}$ by an immunisation protocol described previously. ${ }^{28}$ Toxin-antitoxin mixture was applied to HeLa cell monolayers and observed for neutralisation of cytotoxicity.

In the $Y 1$ cell assay, rounding of $\geqslant 50 \%$ cells was considered to be a positive result for heat-labile toxin, in the HeLa cell assay, detachment of $\geqslant 50 \%$ cells was considered to be a positive result for cytotoxin, and in the suckling mouse assay, the gut weight to remaining body weight ratio of $\geqslant 0.085$ was considered a positive result for heat-stable toxin.

\section{Congo-red binding}

Congo-red binding of bacteria was tested by streaking the organisms on Congo-red agar and observing for the development of pigmented colonies as described previously. ${ }^{29}$

\section{Salt aggregation test}

Bacteria grown on trypticase soy agar for $18 \mathrm{~h}$ at $37^{\circ} \mathrm{C}$ were used to determine cell surface hydrophobicities by checking their agglutination in different concentrations of ammonium sulphate in a slide test. ${ }^{29}$

\section{Antibiogram}

The antibiotic susceptibilities of bacteria were tested by the disk diffusion method ${ }^{30}$ against tetracycline, ampicillin, chloramphenicol, streptomycin, kanamycin, gentamicin, carbenicillin, pivmecillinam, ceftriaxone, nalidixic acid and trimethoprim-sulphamethoxazole.

\section{Results}

\section{Antigenic characteristics of isolates}

All three isolates of $P$. shigelloides (12726, 22074 and 12254) gave strong and rapid slide agglutination reactions with $S$. flexneri polyvalent antiserum (Wellcome Diagnostics, Dartford), S. flexneri 6 monospecific polyclonal antiserum (Wellcome Diagnostics) and the MASFB MAb. They were not agglutinated with other shigella antisera. The reaction patterns of shigellae against $P$. shigelloides antiserum are shown in table $\mathrm{I}$. The $S$. dysenteriae 1 isolate and all $S$. flexneri serotypes were agglutinated by the antiserum.

In the tube agglutination test (table II) with $P$. shigelloides antiserum, there was one dilution difference between homologous and heterologous titres,

Table I. Slide agglutination of live and boiled cells of shigellae with antiserum to $P$. shigelloides strain 12726

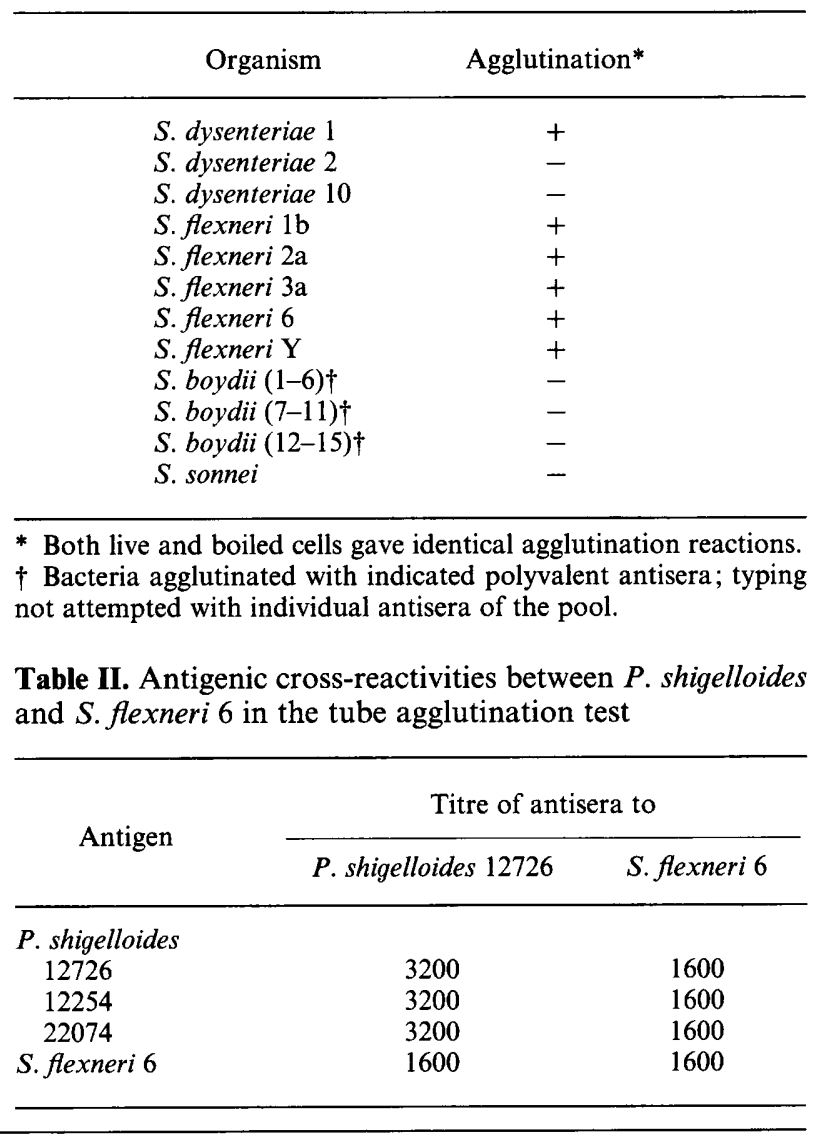


Table III. Antigenic cross-reactivities between P. shigelloides and S. flexneri 6 in ELISA

\begin{tabular}{lcccc}
\hline LPS antigen from & \multicolumn{3}{c}{ Titre of antisera to } & \multirow{2}{*}{$\begin{array}{c}\text { Titre of } \\
\text { MASFB MAb }\end{array}$} \\
\cline { 2 - 4 } & $\begin{array}{c}\text { P. shigelloides } \\
12726\end{array}$ & S. flexneri 6* & S. flexneri 6 $\dagger$ & \\
\hline $\begin{array}{l}\text { P. shigelloides 12726 } \\
\text { S. flexneri 6 }\end{array}$ & 1000000 & 10000 & 10000 & 100000 \\
& 10000 & 1000000 & 100000 & 100000 \\
\hline
\end{tabular}

* Unabsorbed rabbit polyclonal antiserum.

$\dagger$ Absorbed Wellcome rabbit polyclonal, monospecific antiserum.
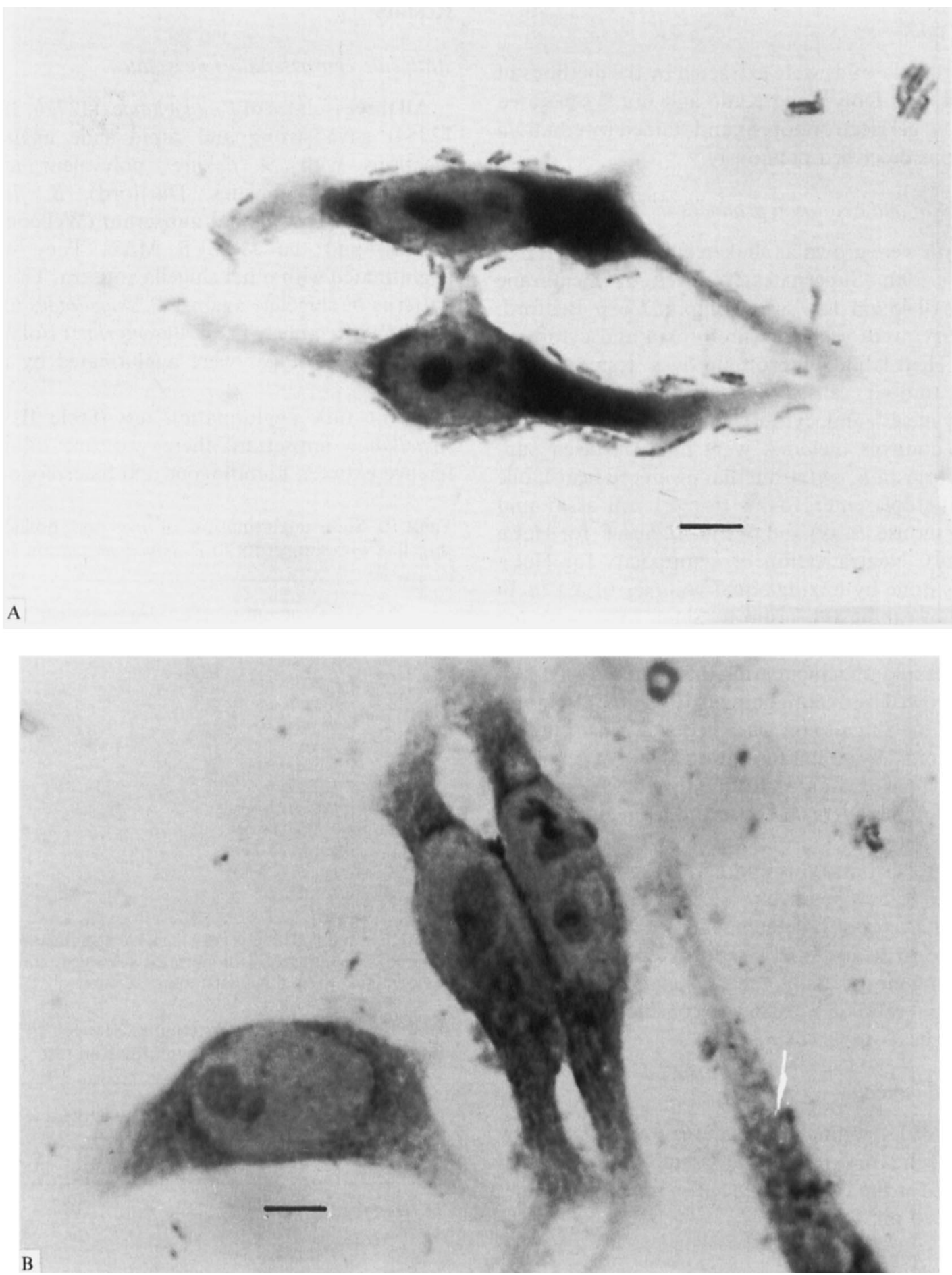

Figure. Adherence of: A, $P$. shigelloides 12254 to HEp-2 cells, compared with B, no adherence to HEp-2 cells inoculated with $P$. shigelloides 22074. Bar, $5 \mu \mathrm{m}$; Giemsa stain. 
whereas homologous and heterologous titres were identical with $S$. flexneri 6 antiserum.

Cross-reactivities in ELISA are shown in table III. The homologous titres of polyclonal antisera were higher than heterologous titres and the differences ranged from 10 -fold to 100 -fold. However, the MASFB MAb gave identical titres against LPS from both bacteria.

The silver-stained gel patterns of LPS from $P$. shigelloides 12726 and S. flexneri 6 showed patterns of smooth organisms-ladder-like patterns representing the O-polysaccharide side-chain and the core lipid A (data not shown).

\section{Cell-culture adherence}

Only $P$. shigelloides strain 12254 showed good adherence to HEp-2 cells both in the presence and absence of D-mannose. The majority of cells had numerous adherent bacteria (fig. A). However, the other two strains did not show any adherence (fig. B).

\section{Invasion}

None of the three isolates caused keratoconjunctivitis in the Sereny test and none gave positive hybridisation results with the $S$. flexneri invasiveness plasmid probe. In the quantitative cell-culture invasion assay, the intracellular survival of bacteria in $\mathrm{cfu} / \mathrm{ml}$ was $4.0 \times 10^{3}$ each for strains 12254 and for 12726 , and $4 \cdot 1 \times 10^{3}$ for strain 22074 . The corresponding values for the positive control $S$. flexneri 2 a and the negative control E. coli K-12 EC101 strains were $1.0 \times 10^{5} \mathrm{cfu}$ and 0 cfu respectively. Thus, it appeared that the $P$. shigelloides strains were invasive for cell cultures.

\section{Enterotoxin and cytotoxin production}

None of the three isolates produced either heatlabile or heat-stable enterotoxins (rounding of $Y 1$ cells $0-1 \%$, gut weight to remaining body weight in suckling mouse assay $0.077-0.079$ ) but all of them produced cytotoxins $(50-80 \% \mathrm{HeLa}$ cells affected) that were not neutralised by Shiga antitoxin. In the assays for cell-culture adherence, invasion and toxins, the control organisms behaved as expected.

\section{Hydrophobicity}

All three isolates formed smooth suspensions in physiological saline. However, all were highly hydrophobic as they agglutinated in $0.06 \mathrm{M}$ ammonium sulphate.

\section{Congo-red binding}

The three isolates bound Congo red, as they produced pigmented colonies on Congo-red agar.

\section{Plasmid profile}

Strain 12726 had a single plasmid ( $2 \cdot 0 \mathrm{MDa})$, strain 22074 had two plasmids $(2 \cdot 0$ and $<1 \mathrm{MDa})$ and strain $12254 \mathrm{had}$ two plasmids (2.7 and $1.8 \mathrm{MDa})$.

\section{Antibiogram}

All the isolates were uniformly susceptible to tetracycline, chloramphenicol, kanamycin, gentamicin, nalidixic acid, trimethoprim-sulphamethoxazole and ceftriaxone, but resistant to ampicillin, streptomycin and carbenicillin.

\section{Discussion}

The three $P$. shigelloides strains agglutinated with Wellcome monospecific polyvalent $S$. flexneri 6 antiserum, which suggested that they possessed the $S$. flexneri 6 type-specific antigen. However, antiserum to live cells of $P$. shigelloides 12726 agglutinated $S$. dysenteriae 1 and all serotypes of $S$. flexneri tested. This suggested that in the bacterial cell, there was an additional antigen(s) shared with $S$. dysenteriae 1 and all $S$. flexneri serotypes. Such an assumption was confirmed by the reactivity of $P$. shigelloides strains with MASFB MAb, which is directed against the common group antigen 1 of $S$. flexneri spp. and $S$. dysenteriae 1 . This common antigenic determinant is $\alpha-1,2$ or $\alpha-1,3$ linked L-rhamnopyranosyl residue in the $\mathrm{O}$-antigenic polysaccharide. ${ }^{9}$ Furthermore, agglutination of boiled cells and the reactivities of purified LPS in ELISA would suggest that the cross-reacting antigens are LPS. Higher titres were obtained in ELISA than in the tube agglutination test, which is attributable to the greater sensitivity of ELISA.

It is unlikely that the three $P$. shigelloides strains are rough and that the cross-reaction is due to an exposed common epitope in rough strains because the strains formed smooth suspensions and reacted with MASFB $\mathrm{MAb}$, which is known to react only with smooth strains, not rough mutants. Moreover, the silverstained LPS structure showed recognition of antigens corresponding to the ladder-like O-polysaccharide side chain of smooth bacteria, and smooth $P$. shigelloides cross-reacting with other shigellae have been demonstrated previously. ${ }^{5}$

Standard laboratory assays were used to see whether these unique isolates possessed some of the established virulence properties of diarrhoeagenic bacteria. The properties investigated included cell-culture adherence, ${ }^{31,32}$ invasiveness in the Sereny test and cell culture, ${ }^{33}$ cytotoxin and enterotoxin production, ${ }^{34,35}$ Congo-red binding, ${ }^{29}$ possession of high mol. wt plasmid ${ }^{33}$ high hydrophobicity ${ }^{29}$ and multiresistance to antibiotics ${ }^{36}$ Only one strain, 12254 , adhered to a HEp-2 cell monolayer, and we know of no previous studies on the cell-culture adherence of $P$. shigelloides. The role of this cell-culture adherence in pathogenicity remains unclear. As found in other studies, ${ }^{3,4,37}$ the strains were not invasive in the Sereny test. However, all strains were invasive in the HEp-2 cell assay although to a lesser extent than the positive $S$. flexneri 2a control strain. A previous report by Binns et al. ${ }^{38}$ also found invasiveness in five of $16 P$. shigelloides 
strains, although other studies failed to identify this property. ${ }^{2,4,39}$ The lack of hybridisation with the 17kb DNA probe demonstrated that our $P$. shigelloides strains lack the gene sequence common to the large invasiveness plasmids found in Shigella spp. and enteroinvasive $E$. coli. Consistent with this observation is the finding that none of the isolates possessed high mol. wt plasmids resembling the invasiveness plasmids of the last two bacteria. Although many strains of $P$. shigelloides were found to harbour high mol. wt plasmids in previous studies, ${ }^{2-4,39}$ sequence homology with the invasiveness plasmids of Shigella spp. and enteroinvasive $E$. coli were not observed. ${ }^{4}$ However, our strains had different plasmid profiles, mainly of smaller plasmids, and the functions of these plasmids remain undefined. All strains bound Congo red dye and exhibited high hydrophobicity, as reported previously. ${ }^{2}$ Our strains did not produce enterotoxins, although this property was found to be variable in previous studies. ${ }^{2,340}$ However, all three isolates produced toxins (unrelated to Shiga toxin) that were cytotoxic for HeLa cells. It is known that Shigella spp. also produce cytotoxins unrelated to Shiga toxin. ${ }^{41}$ Previous studies also found similar cytotoxin production by $P$. shigelloides strains $\mathrm{s}^{2,42}$ and it is possible that such cytotoxic activity could be a potential virulence factor in $P$. shigelloides-associated gastroenteritis. Multiresistance to antibiotics did not seem to be a problem with the isolates, as they were susceptible to most of the antibiotics tested.

\section{References}

1. Brenden RA, Miller MA, Janda JM. Clinical disease spectrum and pathogenic factors associated with Plesiomonas shigelloides infections in humans. Rev Infect Dis 1988; 10: 303-316.

2. Abbott SL, Kokka RP, Janda JM. Laboratory investigations on the low pathogenic potential of Plesiomonas shigelloides. $J$ Clin Microbiol 1991; 29: 148-153.

3. Olsvik O, Wachsmuth K, Kay B, Birkness KA, Yi A, Sack B Laboratory observations on Plesiomonas shigelloides strains isolated from children with diarrhea in Peru. $J$ Clin Microbiol 1990; 28 : 886-889.

4. Herrington DA, Tzipori S, Robins-Browne RM, Tall BD, Levine MM. In vitro and in vivo pathogenicity of Plesiomonas shigelloides. Infect Immun 1987; 55: 979-985.

5. Shimada T, Sakazaki R. On the serology of Plesiomonas shigelloides. Jpn J Med Sci Biol 1978; 31 : 135-142.

6. Rahim Z, Kay BA. Enrichment for Plesiomonas shigelloides from stools. J Clin Microbiol 1988; 26: 789-790.

7. WHO. Manual for laboratory investigations of acute enteric infections. Geneva, World Health Organization, 1987: 9-20.

8. von Graevenitz A. Aeromonas and Plesiomonas. In: Lennette EH, Balows A, Hausler WJ, Shadomy HJ (eds) Manual of clinical microbiology, 4th edn. Washington D.C., American Society for Microbiology. 1985: 278-281.

9. Carlin NIA, Lindberg AA. Monoclonal antibodies specific for Shigella flexneri lipopolysaccharides: clones binding to type IV, V, and VI antigens, group 3, 4 antigen, and an epitope common to all Shigella flexneri and Shigella dysenteriae type 1 strains. Infect Immun 1987; 55: 1412-1420.

10. Westphal O, Jann K. Bacterial lipopolysaccharide: extractions with phenol-water and further applications of the procedure. Methods Carbohydr Chem 1975; 5: 83-91.

11. Lindberg AA, Haeggman S, Karlsson K, Cam PD, Trach DD.
Contrary to the previous studies, which found low pathogenic potential for $P$. shigelloides, ${ }^{2-4}$ we demonstrated that the three strains that shared antigens with Shigella spp. seemed to possess at least four virulence-associated properties of shigellae, namely epithelial cell invasiveness, cytotoxicity, Congo-red binding and high hydrophobicity. One strain (no. 12254) also possessed cell-culture adherence. This would suggest that the three strains might be pathogenic. However, for reasons of economy, studies were confined to pathogens requested by physicians (see Materials and methods), and other pathogens such as parasites and viruses were not sought in these patients. Therefore, the role of $P$. shigelloides as the causative agents of diarrhoea in these patients could not be established unequivocally. Further studies with experimental animals and human volunteers would be necessary to establish the diarrhoeagenic potential of these unique isolates.

In a previous study, ${ }^{2}$ some $P$. shigelloides were found to agglutinate with polyvalent $S$. flexneri antiserum, not type-specific antisera. Our study has further demonstrated strains that cross-react with a serotypespecific antiserum. The present and the previous data ${ }^{5}$ suggest that antigenic cross-reactions between Shigella spp. and $P$. shigelloides are not uncommon, and this will have implications for cross-protection.

This research was supported by the International Centre for Diarrhoeal Disease Research, Bangladesh (ICDDR, B). We thank M. Haque of ICDDR, B for secretarial assistance.
The humoral antibody response to Shigella dysenteriae type 1 infection, as determined by ELISA. Bull WHO 1984; 62: $597-606$

12. Laemmli UK. Cleavage of structural proteins during the assembly of the head of bacteriophage T4. Nature 1970 ; 227: $680-685$

13. Hitchcock PJ, Brown TM. Morphological heterogeneity among Salmonella lipopolysaccharide chemotypes in silver-stained polyacrylamide gels. J Bacteriol $1983 ; 154$ : 269-277.

14. Cravioto A, Gross RJ, Scotland SM, Rowe B. An adhesive factor found in strains of Escherichia coli belonging to the traditional infantile enteropathogenic serotypes. Curr Microbiol 1979; 3: 95-99.

15. Ashraf MH, Ahmed ZU, Sack DA. Unusual association of a plasmid with nalidixic acid resistance in an epidemic strain of Shigella dysenteriae type 1 from Asia. Can J Microbiol $1991 ; 37$ : 59-63.

16. Small PLC, Falkow S. Identification of regions on a 230kilobase plasmid from enteroinvasive Escherichia coli that are required for entry into HEp-2 cells. Infect Immun 1988; 56: $225-229$.

17. Sereny B. Experimental Shigella kerato-conjunctivitis: a preliminary report. Acta Microbiol Acad Sci Hung 1955; 2 : 293-296.

18. Sethabutr $O$, Hanchalay $S$, Echeverria $P$, Taylor DN, Leksomboon U. A non-radioactive DNA probe to identify Shigella and enteroinvasive Escherichia coli in stools of children with diarrhoea. Lancet 1987 ; 2: 1095-1097.

19. Moseley SL, Echeverria P, Seriwatana J et al. Identification of enterotoxigenic Escherichia coli by colony hybridization using three enterotoxin gene probes. $J$ Infect Dis 1982; 145: 863-869.

20. Maniatis T, Fritsch EF, Sambrook J. Molecular cloning: a laboratory manual. Cold Spring Harbor, New York, Cold Spring Harbor Laboratory. 1982: 109-112.

21. Echeverria P, Taylor DN, Seriwatana J, Brown JE, Lexomboon U. Examination of colonies and stool blots for detection of 
enteropathogens by DNA hybridization with eight DNA probes. J Clin Microbiol 1989; 27: 331-334.

22. Birnboim HC, Doly J. A rapid alkaline extraction procedure for screening recombinant plasmid DNA. Nucleic Acids Res 1979; 7: 1513-1523.

23. Kado CI, Liu S-T. Rapid procedure for detection and isolation of large and small plasmids. J Bacteriol 1981; 145: 1365-1373.

24. Meyers JA, Sanchez D, Elwell LP, Falkow S. Simple agarose gel electrophoretic method for the identification and characterization of plasmid deoxyribonucleic acid. J Bacteriol 1976; 127: 1529-1537.

25. Sack DA, Sack RB. Test for enterotoxigenic Escherichia coli using Y-1 adrenal cells in miniculture. Infect Immun 1975; 11: 334-336.

26. Dean AG, Ching Y-C, Williams RG, Harden LB. Test for Escherichia coli enterotoxin using infant mice: application in a study of diarrhea in children in Honolulu. J Infect Dis $1972 ; 125$ : 407-411.

27. Gentry MK, Dalrymple JM. Quantitative microtiter cytotoxicity assay for Shigella toxin. J Clin Microbiol 1980; 12: 361-366.

28. Donohue-Rolfe A, Keusch GT, Edson C, Thorley-Lawson D, Jacewicz M. Pathogenesis of Shigella diarrhea. IX. Simplified high yield purification of Shigella toxin and characterization of subunit composition and function by the use of subunit-specific monoclonal and polyclonal antibodies. J Exp Med 1984; 160: 1767-1781.

29. Qadri F, Hossain SA, Čižnár I et al. Congo red binding and salt aggregation as indicators of virulence in Shigella species. $J$ Clin Microbiol 1988; 26: 1343-1348.

30. Bauer AW, Kirby WMM, Sherris JC, Turck M. Antibiotic susceptibility testing by a standardized single disk method. Am J Clin Pathol 1966; 45: 493-496.

31. Pal T, Hale TL. Plasmid-associated adherence of Shigella flexneri in a HeLa cell model. Infect Immun 1989; 57 : $2580-2582$.
32. Nataro JP, Kaper JB, Robins-Browne R, Prado V, Vial P, Levine MM. Patterns of adherance of diarrheagenic Escherichia coli to HEp-2 cells. Pedriatr Infect Dis $J$ 1987; 6: 829-831.

33. Sansonetti PJ, Kopecko DJ, Formal SB. Involvement of a plasmid in the invasive ability of Shigella flexneri. Infect Immun 1982; 35: 852-860.

34. O'Brien AD, Thompson MR, Gemski P, Doctor BP, Formal SB. Biological properties of Shigella flexneri $2 \mathrm{a}$ toxin and its serological relationship to Shigella dysenteriae 1 toxin. Infect Immun 1977; 15: 796-798.

35. Marques LRM, Moore MA, Wells JG, Wachsmuth IK, O'Brien AD. Production of Shiga-like toxin by Escherichia coli. $J$ Infect Dis 1986; 154: 338-341.

36. Haider K, Albert MJ, Nahar S, Kibriya AKMG. Plasmidassociated resistance to pivmecillinam in Shigella flexneri and Shigella boydii. J Antimicrob Chemother 1991; 28: 599-601.

37. Pitarangsi C, Echeverria P, Whitmire R et al. Enteropathogenicity of Aeromonas hydrophila and Plesiomonas shigelloides: prevalence among individuals with and without diarrhea in Thailand. Infect Immun 1982; 35: 666-673.

38. Binns MM, Vaughan S, Sanyal SC, Timmis KN. Invasive ability of Plesiomonas shigelloides. Zentralbl Bakteriol Mikrobiol Hyg A 1984; 257: 343-347.

39. Nolte FS, Poole RM, Murphy GW, Clark C, Panner BJ. Proctitis and fatal septicemia caused by Plesiomonas shigelloides in a bisexual man. J Clin Microbiol 1988; 26 : 388-391.

40. Gardner SE, Fowlston SE, George WL. In vitro production of cholera toxin-like activity by Plesiomonas shigelloides. $J$ Infect Dis 1987; 156: 720-722.

41. O'Brien AD, Holmes RK. Shiga and Shiga-like toxins. Microbiol Rev 1987; 51: 206-220.

42. Hostacká A, Cižnár I, Korych B, Karolček J. Toxic factors of Aeromonas hydrophila and Plesiomonas shigelloides. Zentralbl Bakteriol Mikrobial Hyg A 1982; 252: 525-534. 